\title{
Mass Spectrometric Study of Colchicine and its Synthetic Derivatives 10-Alkylthiocolchicines
}

\author{
Joanna Kurek, $^{1, *}$ Zdzisława Nowakowska $^{1}$ and Grażyna Bartkowiak ${ }^{1,2}$ \\ ${ }^{1}$ Faculty of Chemistry, A. Mickiewicz University, Grunwaldzka 6, 60-780 Poznań, Poland \\ ${ }^{2}$ NanoBioMedical Centre, A. Mickiewicz University, Umultowska 85, 61-614 Poznań, Poland \\ * Corresponding author: E-mail: joankur@amu.edu.pl
}

Received: 13-10-2014

\begin{abstract}
The mass spectra behaviour of five 10-alkylthiocolchicine derivatives has been studied using electron ionization and MALDI-TOF MS techniques. Fragmentation patterns of colchicines derivatives after EI have been investigated, as well as mass spectra after collision-induced dissociation (CID) MALDI have been used to gain structural information. To the best of our knowledge, this is the first time that the MALDI MS/MS data for colchicine and its alkylthio derivatives have been described. It has been shown also that the data derived from mass spectra can be used for identification/quantitative determination of natural and modified alkaloids of colchicine group. The detailed fragmentation pathways proposed here could be helpful for the characterization of other colchicines of these type. The utility of different ionization techniques for analysis of compounds of this class has been evaluated. Due to the cytotoxic activity towards tumour cell lines, 10-alkylthiocolchicines may be considered as the active ingredients of anticancer agents. If these compounds find use in medical treatment, their distribution in organism and their metabolism will have to be monitored by spectroscopic or spectrometric methods. The characteristic fragment ions may be used by Selected Reaction Monitoring method for determination of colchicine analogues.
\end{abstract}

Keywords: Colchicine, 10-alkylthiocolchicine derivatives, EI-MS mass spectra, fragmentation pathways, MALDITOF MS of colchicine derivatives

\section{Introduction}

Colchicine is an alkaloid occurring in plants of $\mathrm{Li}^{-}$ liaceae family especially in meadow saffron Colchicum autumnale and Gloriosa superba and it is best known for its antimitotic effects. ${ }^{1-3}$ The extract from the plants containing this compound has been well known for ages as a medicine against gout as first described in De Materia Medica by Pedanius Dioscorides. ${ }^{4}$ Colchicine can efficiently alleviate the symptoms during gout attacks when applied in the early phase because of its anti-inflammatory properties. More recently it has been introduced for the treatment of the Familial Mediterranean Fever (FMF) and liver diseases. ${ }^{5,6}$ It is known that colchicine is able to interfere with the structure of mitotic spindle and hence inhibit mitosis. ${ }^{7}$ This is one of the reasons that colchicine and some of its derivatives are useful as anticancer drug components. Application of colchicine for medical purposes is however limited due to its poisoning properties. The modification of molecular structure has a strong influence on the biological activity of compounds. Introducing alkylthio groups of different length to the colchicine molecule not only alters its shape, but also influences its complexing ability due to the sulfur atom and changes electron density distribution in the molecule due to the electron-donating properties of the alkyl group. Such a modification of colchicine molecule may significantly transform its mode of action. The introduced alkyl chain is likely to change the key-lock binding in the living cells of the compounds obtained. Our research is directed toward the derivatives of decreased toxicity in comparison with colchicine itself, but of retained pharmacological activity. The compounds studied exhibited higher anticancer activity than doxorubicin and lower toxicity than colchicine. ${ }^{8}$ The modified colchicine derivatives can find applications as drug components and their metabolism could be investigated by means of commonly used metabolomic techniques, involving wide range of mass spectrometric methods. For detection of metabolites in body fluids most 
often hyphenated techniques GC-MS or HPLC-MS are used, often in combination with electron ionization (EI). EI MS spectra are characterized by good repeatability, therefore knowledge of the fragmentation pattern allows complete identification of the compound.

Such MS techniques like MALDI-TOF MS enable extremely high throughput up to thousands samples a day without a laborious preparation of the sample, so it is an ideal technique for biomedical screening tests. The direct measurement of an intrinsic property of the analyte molecules, i.e. their molecular weights, is an irreplaceable technique for compound identification, moreover, it can be supplemented by fragmentation spectra, obtained through the collisions with neutral gas molecules. The knowledge of characteristic fragment ions for the given compound ensures its authentication and can be used in selected ion monitoring method of drug metabolite identification in complex biological mixtures. Distribution of the chemotherapeutic agents in the tissues of an organism can be monitored using MALDI imaging. Taking into account these facts it appears very important to examine this class of potentially pharmacologically active compounds using the variety of mass spectral ionization techniques in order to learn their behavior under different mass spectral conditions and establish the fragmentation pattern of colchicine derivatives. The collected data allow to establish basis for the monitoring of these alkaloids and their metabolites in organisms and physiological fluids.

A number of colchicine derivatives have been synthesized and a lot of them have been screened for their carcinogenic activity. ${ }^{9}$ Some of these derivatives have been characterized by means of mass spectra methods, but the mass spectrometry of 10-alkylthiocolchcines has not been published so far, while the EI and ESI mass spectra of colchicine itself are known and described in chemical literature. ${ }^{10,11}$ The MS methods have been used to establish fragmentation patterns of some colchicine analogues and for detection and identification of components in Colchicum species, whereas mass spectrometry with liquid chromatography, LC/ESI-MS/MS or LC-APCI-MS, have found application in detection of colchicine in sheep serum and milk and in human blood plasma. ${ }^{10,12-18}$

In the present work five 10-alkylthiocolchicine derivatives (Figure 1) were investigated for the principal fragmentation pathways of the molecular ions using EI and protonated molecules using MALDI mass spectrometry. Colchicine was used as the reference compound and its fragmentation spectra were compared with literature data, obtained by using other methods of soft ionization. The isomers could be differentiated by the data derived from electron-ionization mass spectra (the relative abundance of the fragment ions and values of coefficients $\mu$ ) and through the comparison of the $[\mathrm{M}+\mathrm{H}]^{+}$precursor ion stability in MALDI MS/MS, which is different for the compounds with normal and branched alkyl chains. The frag-

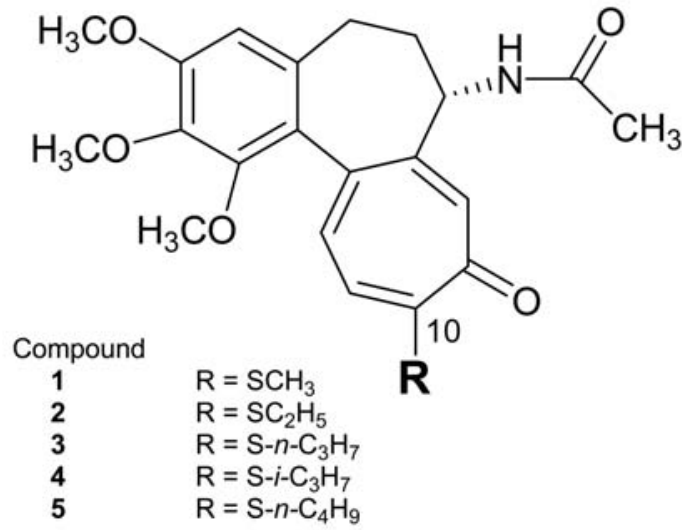

Fig. 1. Structures of 10-thioalkylcolchicine derivatives studied

mentation rules deduced here could help in the characterization of other colchicines of these type. The distinctive ions from MALDI mass spectra may be used for selected ion monitoring (SIM) / multiple reaction monitoring (MRM) in detection and determination of colchicine and its derivatives in pharmaceuticals, herbal medicines and human fluids, specifically blood and urine of patients undergoing medical treatment with use of natural or modified colchicine alkaloids.

\section{Experimental}

\section{1. Material}

10-Alkylthiocolchicine derivatives 1-5 were prepared according to the literature. ${ }^{8}$ The melting point measurements and thin layer chromatography data proved purity of the compounds obtained. The mass spectrometric data fully confirmed the high purity of $\mathbf{1 - 5}$, since there were no traces of unreacted substrates or side products in the spectra (related $[\mathrm{M}+\mathrm{H}]^{+}$ions, originated from impurities, had not been noticed).

\section{2. Mass Spectrometry}

The EI mass spectra were recorded on an AMD-402 two-sector mass spectrometer (AMD Intectra GmbH Co. Harpstedt, Germany) with an acceleration voltage of $8 \mathrm{kV}$, electron energy $70 \mathrm{eV}$, mass resolution 6000, and an ion source temperature of $\sim 150^{\circ} \mathrm{C}$. The samples $\mathbf{1}-\mathbf{5}$ were introduced using a direct insertion probe. The linked-scan at constant $B^{2} / E$ and $B / E$ mass spectra of metastable ions and exact mass measurements for the ions of interest were recorded on the same instrument. High resolution data were obtained by using a $V / E$ high resolution scan in relation to perfluorokerosene (PFK), with an error of less than $10 \mathrm{ppm}$ for all the ions discussed. The $B^{2} / E$ and $B / E$ linked-scan mass spectra in the first field-free region were recorded using helium as the collision gas at the indicated pressure of $1.73 \times 10^{-5} \mathrm{~Pa}$ at the ion source tempe- 
rature of $180{ }^{\circ} \mathrm{C}$, the ionization energy of $70 \mathrm{eV}$, and accelerating voltage of $8 \mathrm{kV}$.

The matrix-assisted laser desorption/ionization measurements, including MS/MS experiments, have been accomplished on Waters Q-TOF Premier instrument, equipped with nitrogen laser MALDI source and MassLynx $^{\mathrm{TM}}$ software. MALDI measurements have been performed in the positive ion mode. In order to prepare the target spots, the methanolic solution containing matrix (1 $\mu \mathrm{L}$, concentration $0.5 \mathrm{~mol} / \mathrm{L}$ ) has been deposited on the spot and allowed to dry at room temperature. After a few minutes $1 \mu \mathrm{L}$ of the solution containing colchicine derivative (the concentration about $1 \mathrm{mmol} / \mathrm{L}$ ) has been placed as a next layer over the dried matrix and left to cocrystallize.

Four different kinds of matrices (2,5-dihydroxybenzoic acid (DHB), sinapic acid (SA), $\alpha$-cyano-4hydroxycinnamic acid (CHCA) and dithranol (DIT)) were used for MALDI-TOF in order to choose the optimal one. All the above mentioned matrices, i.e. DHB, SA, CHCA and DIT, enabled a sufficient protonation of the analyte molecules and for all compounds studied $[\mathrm{M}+\mathrm{H}]^{+}$ion peaks have been observed, however dithranol appeared to give the best response and signal-to-noise ratio. CHCA as a matrix seemed to strongly stimulate the dehydrogenation of analyte molecules, because the $\left[\mathrm{M}-\mathrm{H}_{2}+\mathrm{H}\right]^{+}$ions appeared in the MALDI spectra of $\mathbf{2 , 3}$, 4 and 5 as the most abundant ones (r.a. 100\%) when CHCA has been applied. The MS/MS experiment with dithranol as the matrix and argon as the colliding neutral gas (at flow rate of $0.5 \mathrm{~mL} / \mathrm{min}$ ) has been performed and the collision-induced fragmentation of protonated molecules $[\mathrm{M}+\mathrm{H}]^{+}$has been analyzed, depending on collision energy CE (Table 4). The product ion MS/MS spectra were collected at four collision energy values, i. e. 10, 20, 30 and $40 \mathrm{eV}$.

It should be noticed the nanospray MS of colchicine and $\mathrm{MS}^{2}$ of the $m / z, 400 \pm 0.5$ ion $[\mathrm{M}+\mathrm{H}]^{+}$have already been reported and representative fragment ions, which originate from $\mathrm{m} / \mathrm{z} 400$, are given, i.e. $\mathrm{m} / \mathrm{z} 382,368,358$, 341, 326, 310, 298 and 282. MALDI MS/MS fully confirms this fragmentation pattern, since the same $\mathrm{m} / \mathrm{z}$ values appear in collisionally induced dissociation as well as in previously published papers. ${ }^{19,20}$

\section{Results and Discussion}

\section{1. Electron-ionization Mass Spectra}

The parameter selected in this study for MS analysis was the relative abundance of electron-ionization mass spectra as it easily provided extensive information via EI induced fragmentations of 10-alkylthiocolchicine. As a part of the investigation, aiming at the differentiation of isomeric derivatives of 10-alkylthiocolchicines on the basis of the values of the coefficients $\mu$, i.e. the abundances of selected even or odd-electron fragment ions relative to the abundances of the corresponding molecular ions, we reported here a detailed analysis of the EI mass spectra of compounds 1-5.

In order to validate the mechanism and structures of the ions proposed, the linked-scan at constant $B^{2} / E$ and $B / E$ mass spectra of metastable ions in the first-free region, and exact mass measurements for a few ions of interest were recorded. Table 1 summarizes the most characteristic fragments observed for molecular ions of compounds 1-5, while the proposed fragmentation pathways for each type of the ion are shown in Scheme 1. Although the structures of the fragment ions can be principally considered as conjectural, we proposed very credible ones.

In the present study some common features, such as the loss of ${ }^{\circ} \mathrm{COCH}_{3}, \mathrm{CO}$ and $\mathrm{NH}_{2} \mathrm{COCH}_{3}$, were observed, consistent with the literature. ${ }^{10,13}$ As shown in Scheme 1, the molecular ions of compounds 1-5 studied can lose CO and $\mathrm{NH}_{2} \mathrm{COCH}_{3}$ molecules to form odd-electron ions $\mathbf{b}, \mathbf{g}$ and $\mathbf{h}$. Ion $\mathbf{h}$, which is very abundant for all compounds, undergoes further fragmentation by a few pathways. Although it is difficult to propose a detailed mechanism for the loss of ${ }^{\circ} \mathrm{CH}_{3}$ from the ion $\mathbf{h}$, it seems to be reasonable that the dominant structure of $\left[\mathbf{h}-{ }^{\circ} \mathrm{CH}_{3}\right]^{+}$is that shown in Scheme 1 of the ion $\mathbf{r}$.

Cleavage at the a bond to the sulphur atom in the ion h gives peaks at $\mathrm{m} / \mathrm{z} 313$ and 281, respectively. During this type of fragmentation we can observe a single $\sigma$ cleavage of the $\mathrm{C}-\mathrm{S}$ bond, with an elimination of the ${ }^{\mathrm{S}} \mathrm{SR}$ or ${ }^{\mathrm{R}} \mathrm{R}$ radi$\mathrm{cal}$, and formation of ions $\mathbf{k}$ or $\mathbf{j}$. In the next step these ions lost ${ }^{\circ} \mathrm{CH}_{3}$ or ${ }^{\circ} \mathrm{SCH}_{3}$ radicals and the odd-electron ion $\mathbf{o}$ at $\mathrm{m} / z, 266$ was obtained.

The next abundant product ion derived from $\mathrm{M}^{+\cdot}$ ions is that formed by the loss of mass 33 . This loss involves a complex skeletal rearrangement related to the loss of the $\mathrm{SH}$ radical. A similar process has already been discussed for substituted stilbenethiols, ${ }^{21}$ benzylthiouracils ${ }^{22}$ and alkylthio-5-bromouracils for which the mechanism of the above loss is proposed. ${ }^{23}$ By analogy, the elimination of the ${ }^{\circ} \mathrm{SH}$ radical leading to the formation of the ion $\mathbf{i}$ from the ion $\mathbf{b}$ was observed. The presence of the ions $\mathbf{e}$ and $\mathbf{d}$ indicates that the molecular ions lost also ${ }^{\circ} \mathrm{R}$ and $\mathrm{RH}$ fragments. A detailed analysis of the EI spectra of the compounds studied showed that the molecular ions undergo a fragmentation by the loss of the 'SR radical. Taking into account that radicals are preferably located on heteroatoms using $n$ electron to form a radical site and that the radical site is a driving force to start a bond cleavage, it may be assumed the ions $\mathbf{f}$ are formed as a result of $i$-cleavage of a structure with the radical site localized on the sulphur atom.

The $[\mathbf{j}-44]^{+}$peak $\mathbf{l}$ is observed at $\mathrm{m} / \mathrm{z}, 269$ in the mass spectra of all compounds studied, and the ion formed should have the same structure as that observed for the elimination of the $\mathrm{CO}$ molecule during the fragmentation of 


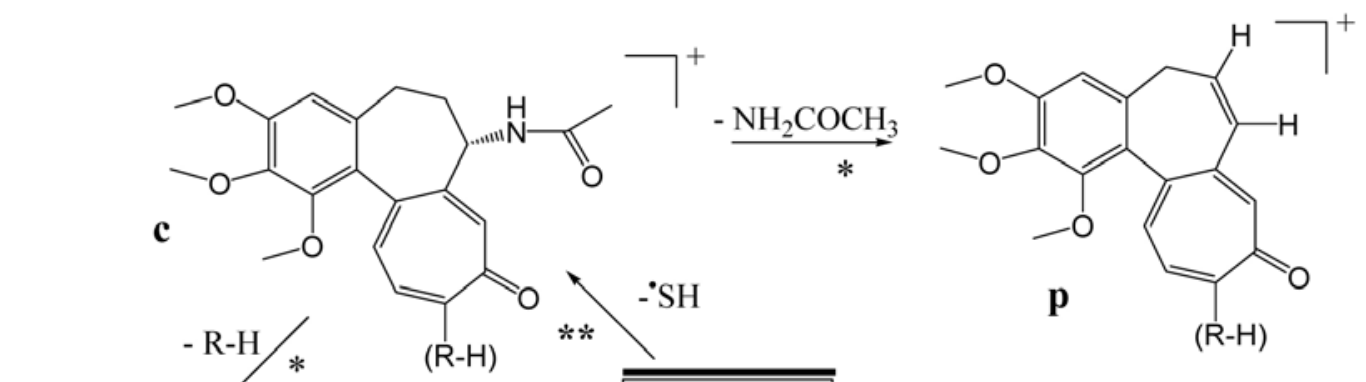<smiles></smiles><smiles>COc1cc2c(c(OC)c1OC)-c1ccc([18F])cc1[C@@H](NC(C)=O)CC2</smiles><smiles>[R7]c1ccc2c(c1)[C@@H](NC(=O)CC(C)=O)CCc1cc(OC)c(OC)c(OC)c1-2</smiles>

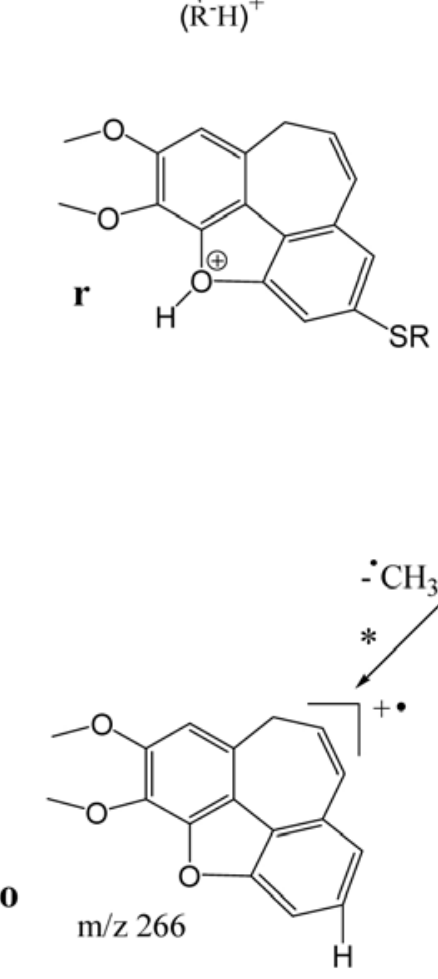

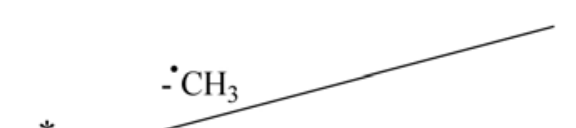<smiles></smiles><smiles>[Y]</smiles><smiles>COc1cc2c(c(OC)c1OC)-c1ccccc1C=CC2</smiles>
$\mathrm{m} / \mathrm{z} 281$

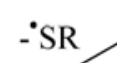<smiles>[R7]c1ccc2c(c1)C=CCc1cc(OC)c(OC)c(OC)c1-2</smiles>
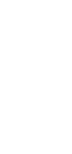

$$
\text { o }
$$
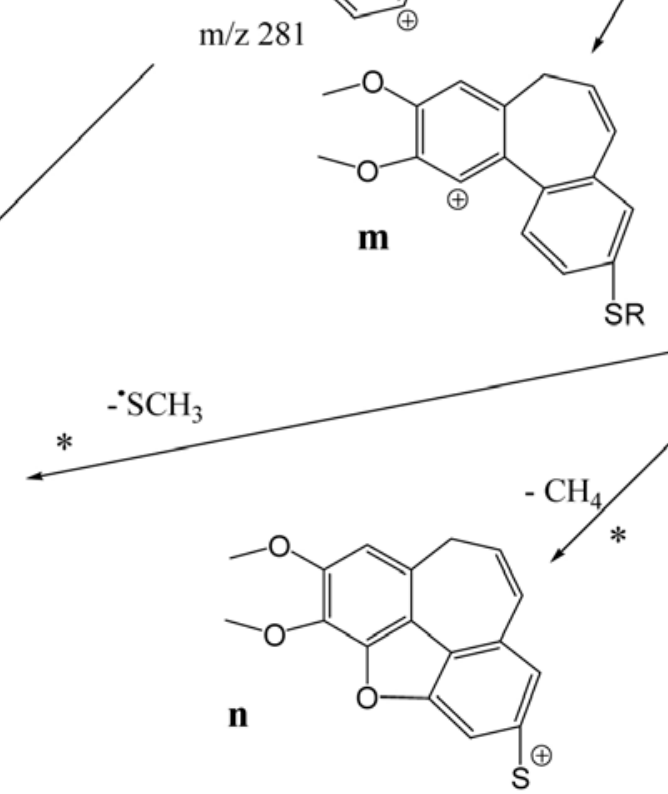

$\mathrm{m} / \mathrm{z} 297$
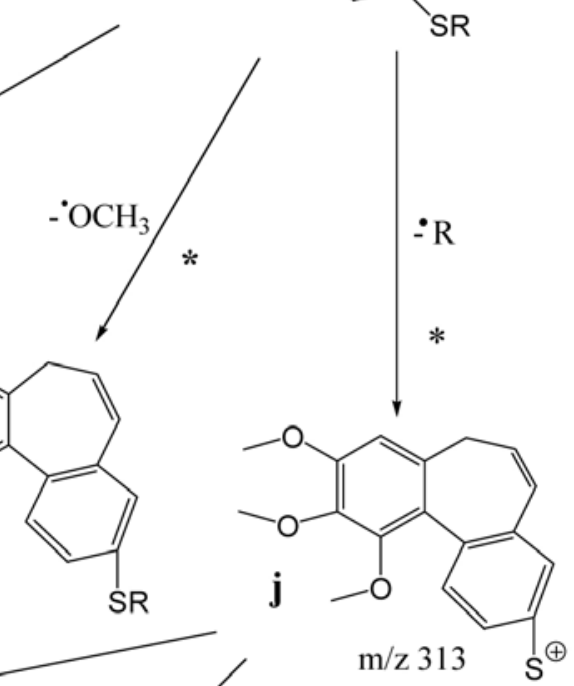

Scheme 1. Proposed main EI fragmentation pathways of molecular ions of compounds 1-5. * Transition checked by $B^{2} / E$ spectra ** Transition checked by $B / E$ spectra 
Table 1. Selected EI mass spectral data $(\mathrm{m} / \mathrm{z}$ and ions abundance in $\%)$ for 1-5.

\begin{tabular}{|c|c|c|c|c|c|c|c|}
\hline \multirow{2}{*}{ Ion } & \multirow{2}{*}{$\begin{array}{l}\text { Elemental * } \\
\text { composition }\end{array}$} & \multirow{2}{*}{$m / z$} & \multicolumn{5}{|c|}{ Relative abundance $(\%)$} \\
\hline & & & 1 & 2 & 3 & 4 & 5 \\
\hline \multirow{4}{*}{$\mathrm{M}^{+\bullet} \mathbf{a}$} & $\mathrm{C}_{22} \mathrm{H}_{25} \mathrm{NO}_{5} \mathrm{~S}$ & 415 & 91.9 & - & - & - & - \\
\hline & $\mathrm{C}_{23} \mathrm{H}_{27} \mathrm{NO}_{5} \mathrm{~S}$ & 429 & - & 70.9 & - & - & - \\
\hline & $\mathrm{C}_{24} \mathrm{H}_{29} \mathrm{NO}_{5} \mathrm{~S}$ & 443 & - & - & 81.6 & 100 & - \\
\hline & $\mathrm{C}_{25} \mathrm{H}_{31} \mathrm{NO}_{5} \mathrm{~S}$ & 457 & - & - & - & - & 79.1 \\
\hline \multirow{4}{*}[\mathrm{M}-\mathrm{CO}]{$^{+\bullet} \mathbf{b}$} & $\mathrm{C}_{21} \mathrm{H}_{25} \mathrm{NO}_{4} \mathrm{~S}$ & 387 & 71.7 & - & - & - & - \\
\hline & $\mathrm{C}_{22} \mathrm{H}_{27} \mathrm{NO}_{4} \mathrm{~S}$ & 401 & - & 33.5 & - & - & - \\
\hline & $\mathrm{C}_{23} \mathrm{H}_{29} \mathrm{NO}_{4} \mathrm{~S}$ & 415 & - & - & 39.1 & 69.5 & - \\
\hline & $\mathrm{C}_{24} \mathrm{H}_{31} \mathrm{NO}_{4} \mathrm{~S}$ & 429 & - & - & - & - & 36.2 \\
\hline \multirow{4}{*}[\mathrm{M}-{}^{\cdot}\mathrm{SH}]{$^{+} \mathbf{c}$} & $\mathrm{C}_{22} \mathrm{H}_{24} \mathrm{NO}_{5}$ & 382 & 35.9 & - & - & - & - \\
\hline & $\mathrm{C}_{23} \mathrm{H}_{26} \mathrm{NO}_{5}$ & 396 & - & 100 & - & - & - \\
\hline & $\mathrm{C}_{24} \mathrm{H}_{28} \mathrm{NO}_{5}$ & 410 & - & - & 100 & 91.0 & - \\
\hline & $\mathrm{C}_{25} \mathrm{H}_{30} \mathrm{NO}_{5}$ & 424 & - & - & - & - & 100 \\
\hline$[\mathrm{M}-\mathrm{RH}]^{+\bullet} \mathbf{d}$ & $\mathrm{C}_{21} \mathrm{H}_{21} \mathrm{NO}_{5} \mathrm{~S}$ & 399 & 19.1 & 57.0 & 7.1 & - & 7.9 \\
\hline$\left[\mathrm{M}-{ }^{\circ} \mathrm{R}\right]^{+} \mathbf{e}$ & $\mathrm{C}_{21} \mathrm{H}_{22} \mathrm{NO}_{5} \mathrm{~S}$ & 400 & 7.5 & 10.0 & 10.7 & 15.8 & 10.8 \\
\hline$\left[\mathrm{M}-{ }^{\circ} \mathrm{SR}\right]^{+} \mathbf{f}$ & $\mathrm{C}_{21} \mathrm{H}_{22} \mathrm{NO}_{5}$ & 368 & 8.2 & 44.1 & 24.5 & 61.8 & 18.9 \\
\hline \multirow{4}{*}[\mathrm{M}-\mathrm{NH}_{2}\mathrm{COCH}_{3}]{$^{+\bullet} \mathbf{g}$} & $\mathrm{C}_{20} \mathrm{H}_{20} \mathrm{O}_{4} \mathrm{~S}$ & 356 & 16.4 & - & - & - & - \\
\hline & $\mathrm{C}_{21} \mathrm{H}_{22} \mathrm{O}_{4} \mathrm{~S}$ & 370 & - & 38.2 & - & - & - \\
\hline & $\mathrm{C}_{22} \mathrm{H}_{24} \mathrm{O}_{4} \mathrm{~S}$ & 384 & - & - & 50.7 & 72.5 & - \\
\hline & $\mathrm{C}_{23} \mathrm{H}_{26} \mathrm{O}_{4} \mathrm{~S}$ & 398 & - & - & - & - & 49.1 \\
\hline \multirow{4}{*}[\mathbf{b}-\mathrm{NH}_{2}\mathrm{COCH}_{3}]{$^{+\cdot} \mathbf{h}$} & $\mathrm{C}_{19} \mathrm{H}_{20} \mathrm{O}_{3} \mathrm{~S}$ & 328 & 100 & - & - & - & - \\
\hline & $\mathrm{C}_{20} \mathrm{H}_{22} \mathrm{O}_{3} \mathrm{~S}$ & 342 & - & 72.4 & - & - & - \\
\hline & $\mathrm{C}_{21} \mathrm{H}_{24} \mathrm{O}_{3} \mathrm{~S}$ & 356 & - & - & 85.2 & 94.2 & - \\
\hline & $\mathrm{C}_{22} \mathrm{H}_{26} \mathrm{O}_{3} \mathrm{~S}$ & 370 & - & - & - & - & 91.5 \\
\hline \multirow{4}{*}[\mathbf{b}-{}^{\cdot}\mathrm{SH}]{$^{+} \mathbf{i}$} & $\mathrm{C}_{21} \mathrm{H}_{24} \mathrm{NO}_{4}$ & 354 & 8.5 & - & - & - & - \\
\hline & $\mathrm{C}_{22} \mathrm{H}_{26} \mathrm{NO}_{4}$ & 368 & - & 42.0 & - & - & - \\
\hline & $\mathrm{C}_{23} \mathrm{~N}_{28} \mathrm{NO}_{4}$ & 382 & - & - & 15.6 & 79.3 & - \\
\hline & $\mathrm{C}_{24} \mathrm{H}_{30} \mathrm{NO}_{4}$ & 396 & - & - & - & - & 16.6 \\
\hline$\overline{\mathbf{j}}$ & $\mathrm{C}_{18} \mathrm{H}_{17} \mathrm{O}_{3} \mathrm{~S}$ & 313 & 38.2 & 30.0 & 14.5 & 23.9 & 20.1 \\
\hline $\mathbf{k}$ & $\mathrm{C}_{18} \mathrm{H}_{17} \mathrm{O}_{3}$ & 281 & 26.1 & 33.6 & 12.3 & 25.1 & 25.5 \\
\hline 1 & $\mathrm{C}_{17} \mathrm{H}_{17} \mathrm{O}_{3}$ & 269 & 10.2 & 11.8 & 8.7 & 17.3 & 15.1 \\
\hline \multirow{4}{*}{ m } & $\mathrm{C}_{18} \mathrm{H}_{17} \mathrm{O}_{2} \mathrm{~S}$ & 297 & 40.1 & - & - & - & - \\
\hline & $\mathrm{C}_{19} \mathrm{H}_{19} \mathrm{O}_{2} \mathrm{~S}$ & 311 & - & 33.3 & - & - & - \\
\hline & $\mathrm{C}_{20} \mathrm{H}_{21} \mathrm{O}_{2} \mathrm{~S}$ & 325 & - & - & 21.3 & 23.9 & - \\
\hline & $\mathrm{C}_{21} \mathrm{H}_{23} \mathrm{O}_{2} \mathrm{~S}$ & 339 & - & - & - & - & 31.8 \\
\hline n & $\mathrm{C}_{17} \mathrm{H}_{13} \mathrm{O}_{3} \mathrm{~S}$ & 297 & 40.1 & 30.3 & 8.3 & 14.6 & 14.8 \\
\hline o & $\mathrm{C}_{17} \mathrm{H}_{14} \mathrm{O}_{3}$ & 266 & 28.5 & 22.9 & 23.9 & 36.2 & 36.7 \\
\hline \multirow{4}{*}{$\mathbf{p}$} & $\mathrm{C}_{20} \mathrm{H}_{19} \mathrm{O}_{4}$ & 323 & 9.8 & - & - & - & - \\
\hline & $\mathrm{C}_{21} \mathrm{H}_{21} \mathrm{O}_{4}$ & 337 & - & 11.5 & - & - & - \\
\hline & $\mathrm{C}_{22} \mathrm{H}_{23} \mathrm{O}_{4}$ & 351 & - & - & 16.0 & 15.0 & - \\
\hline & $\mathrm{C}_{23} \mathrm{H}_{25} \mathrm{O}_{4}$ & 365 & - & - & - & - & 70.1 \\
\hline \multirow{4}{*}{$\mathbf{r}$} & $\mathrm{C}_{18} \mathrm{H}_{17} \mathrm{O}_{3} \mathrm{~S}$ & 313 & 38.2 & - & - & - & - \\
\hline & $\mathrm{C}_{19} \mathrm{H}_{19} \mathrm{O}_{2} \mathrm{~S}$ & 327 & - & 24.9 & - & - & - \\
\hline & $\mathrm{C}_{20} \mathrm{H}_{21} \mathrm{O}_{2} \mathrm{~S}$ & 341 & - & - & 23.7 & 31.1 & - \\
\hline & $\mathrm{C}_{21} \mathrm{H}_{23} \mathrm{O}_{2} \mathrm{~S}$ & 355 & - & - & - & - & 45.2 \\
\hline
\end{tabular}

* The accurate mass differences between the calculated and experimental composition of ions range from 1-10 ppm.

colchicine. ${ }^{10,13}$ According to the linked-scan at constant $B^{2} / E$ spectra, the fragment ion $\mathbf{p}$ may be obtained from the precursor ion $\mathbf{c}$ by the elimination of the $\mathrm{NH}_{2} \mathrm{COCH}_{3}$ molecule. This investigation was also undertaken to find out whether it is possible to differentiate between the isomeric 10- $n$-propylthiocolchicine (3) and 10-thio-iso- propylcolchicine (4) on the basis of the relative abundance of the selected fragment ions (Figure 2, Table 2).

The differences among the fragmentations within the couple of isomeric compounds were expressed quantitatively by comparing the calculated values of the coefficients $\mu$, Table 3 . It should be emphasized that because 
a)

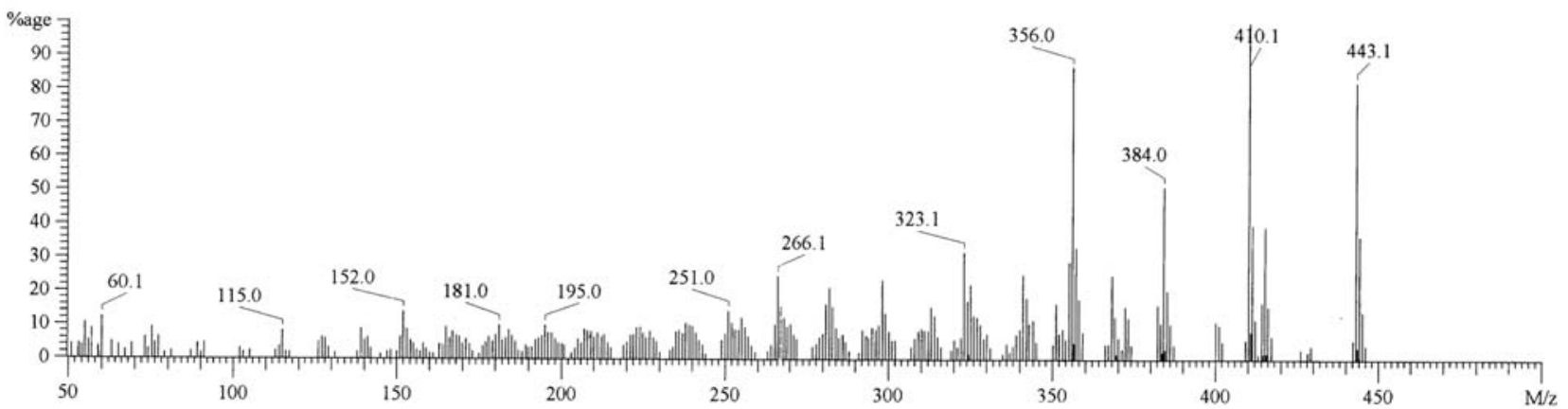

b)

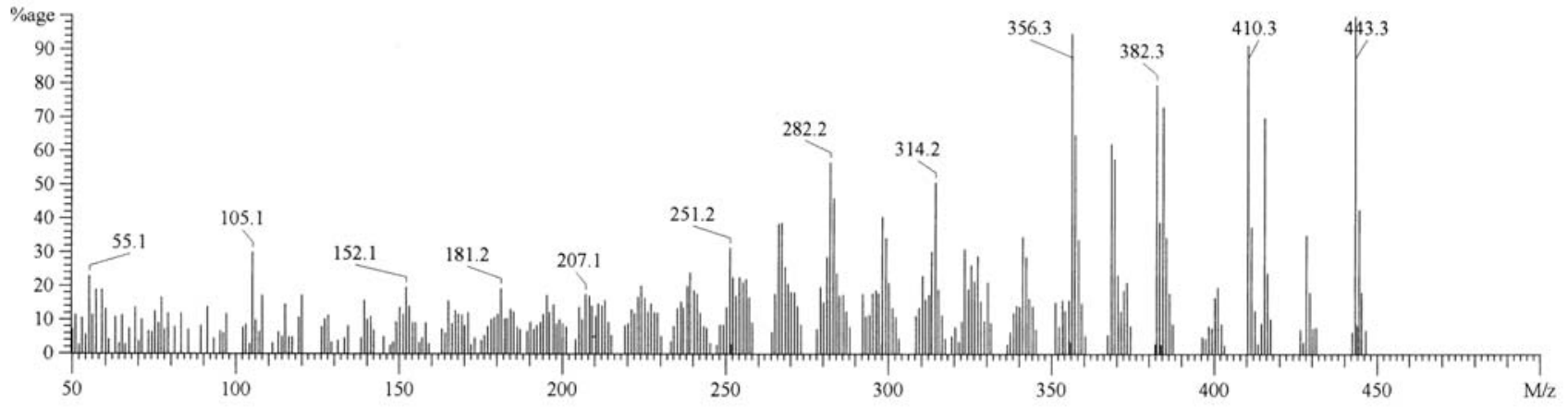

Fig. 2. The EI mass spectra of 10-thio-propylcolchicines a) n-propyl isomer 3 b) iso-propyl isomer 4

Table 2. Relative abundance of ions in the EI mass spectra of isomeric 3 and $\mathbf{4}$ compounds.

\begin{tabular}{|c|c|c|c|c|}
\hline \multirow{2}{*}{ Ion } & \multirow{2}{*}{$\begin{array}{l}\text { Elemental } \\
\text { composition }\end{array}$} & \multirow{2}{*}{$m / z$} & \multicolumn{2}{|c|}{ Relative abundance (\%) } \\
\hline & & & 3 & 4 \\
\hline$\left[\mathrm{M}^{+\bullet}-{ }^{\bullet} \mathrm{CH}_{3}\right]^{+}$ & $\mathrm{C}_{23} \mathrm{H}_{26} \mathrm{NO}_{5} \mathrm{~S}$ & $428 * *$ & 1.7 & 34.8 \\
\hline$\left[\mathrm{M}^{+\bullet}-\mathrm{CO}\right]^{+\bullet}$ & $\mathrm{C}_{23} \mathrm{H}_{29} \mathrm{NO}_{4} \mathrm{~S}$ & $415 * *$ & 39.1 & 69.5 \\
\hline$\left[\mathbf{b}-{ }^{-} \mathrm{SH}\right]^{+}$ & $\mathrm{C}_{23} \mathrm{H}_{28} \mathrm{NO}_{4}$ & 382 & 15.6 & 79.2 \\
\hline $\begin{array}{l}{\left[\mathrm{m} / \mathrm{z} 428-\mathrm{NH}_{2} \mathrm{COCH}_{3}\right]^{+}} \\
\text {or }\left[\mathbf{g}-{ }^{\cdot} \mathrm{CH}_{3}\right]^{+}\end{array}$ & $\mathrm{C}_{21} \mathrm{H}_{21} \mathrm{NO}_{4} \mathrm{~S}$ & $369 *$ & 6.5 & 43.4 \\
\hline$\left[\mathrm{M}^{+\bullet}-{ }^{-} \mathrm{SR}\right]^{+}$ & $\mathrm{C}_{21} \mathrm{H}_{22} \mathrm{NO}_{5}$ & 368 & 24.5 & 61.8 \\
\hline$\left[\mathbf{b}-{ }^{-} \mathrm{NHCOCH}_{3}\right]^{+}$ & $\mathrm{C}_{21} \mathrm{H}_{25} \mathrm{O}_{3} \mathrm{~S}$ & 357 & 13.3 & 42.9 \\
\hline$\left[\mathbf{h}-\mathrm{CH}_{2}=\mathrm{CHCH}_{3}\right]^{+\bullet}$ & $\mathrm{C}_{18} \mathrm{H}_{18} \mathrm{O}_{3} \mathrm{~S}$ & 314 & 9.5 & 44.5 \\
\hline$[\mathrm{m} / \mathrm{z} 314-\mathrm{S}]^{+\bullet}$ & $\mathrm{C}_{18} \mathrm{H}_{8} \mathrm{O}_{3}$ & 282 & 17.7 & 50.4 \\
\hline
\end{tabular}

* Transition checked by $B^{2} / E$ spectra ** Transition checked by $B / E$ spectra

the values of $\mu$ are highly dependent on the relative abundances of the ions, results of three independent measurements were averaged. This procedure guarantees that the results with the differences of the relative abundances of the ions on level of $2-3 \%$ between each particular scan are reliable.

As shown in Table 3, 10-thio- $n$-propylcolchicine (3) may be differentiated from the isomeric 10-thio-iso-

$$
\begin{aligned}
& \mu_{1}=\frac{\left[M^{+\bullet}-C O\right]^{+\bullet}}{M^{+\bullet}} \quad \mu_{2}=\frac{\left[M^{+\bullet}-\cdot S R\right]^{+}}{M^{+\bullet}} \quad \mu_{3}=\frac{\left[M^{+\bullet}-C O-\cdot S H\right]^{+}}{M^{+\bullet}} \\
& \mu_{4}=\frac{\left[M^{+\bullet}-^{\bullet} \mathrm{CH}_{3}\right]^{+}}{M^{+\bullet}} \quad \mu_{5}=\frac{\left[\frac{m / z}{z^{+}} 314\right]^{+\bullet}}{M^{+\bullet}}
\end{aligned}
$$


Table 3. The values of $\mu_{1}-\mu_{5}$ calculated from the EI mass spectra of isomeric 3 and 4 compounds.

\begin{tabular}{lcc}
\hline $\boldsymbol{\mu}$ values & $\mathbf{3}$ & $\mathbf{4}$ \\
\hline$\mu_{1}$ & 0.48 & 0.69 \\
$\mu_{2}$ & 0.30 & 0.61 \\
$\mu_{3}$ & 0.19 & 0.79 \\
$\mu_{4}$ & 0.02 & 0.35 \\
$\mu_{5}$ & 0.11 & 0.44 \\
\hline
\end{tabular}

propylcolchicine (4) on the basis of the lower values of all $\mu_{1}-\mu_{5}$ coefficients.

The differences between relative abundances of the selected fragment ions observed in the spectra of compound $\mathbf{3}$ and $\mathbf{4}$ (Table 3, Figure 2) may be also sufficient to differentiate among the isomeric $n$-propyl and iso-propyl substituted derivatives.

In the series of isomeric 10-propylthiocolchicines, isomer 3 shows the lower relative abundance of the all ions presented in Table 2. In the spectra of 10-isopropylthiocolchicine (4) an intense ion $\left[\mathrm{M}^{+\cdot}-{ }^{-} \mathrm{CH}_{3}\right]^{+}$at $\mathrm{m} / \mathrm{z}$ 428 was observed. One of the possible mechanisms rationalizing this fragmentation is the radical-site initiated a-cleavage of the $\mathrm{C}_{\mathrm{sp} 3}-\mathrm{C}_{\mathrm{sp} 3}$ bond in the iso-propylthio substituent. The $B^{2} / E$ mass spectra of metastable ions recorded for the ion at $\mathrm{m} / \mathrm{z} 369$ have shown two precursor ions. One can be attributed to the ion $\mathbf{g}$, and the second to the ion at $\mathrm{m} / \mathrm{z} 428$.

\section{2. MALDI Mass Spectra}

Till now only colchicine and its interaction with tubulin were examined by MALDI mass spectrometric techniques. $^{24,25}$ This fact has prompted us to examine the series of other biologically active colchicine derivatives, i.e. 10-alkylthiocolchicines 1-5 by MALDI-TOF MS and MALDI-QTOF MS/MS techniques.

According to the MALDI MS/MS measurements performed, no fragmentation occurs at $\mathrm{CE}=10 \mathrm{eV}$, whereas at $20 \mathrm{eV}$ a dissociation of $\mathbf{C o l}$ and $\mathbf{1 - 5}$ protonated molecules is evident, but it proceeds according to another pattern in comparison with electron-induced fragmentation. In MALDI CID prevails dissociation with neutral losses and radical reactions are relatively rare. Typical for thioethers electroninduced MS loss of ${ }^{\circ} \mathrm{SH}$ radical $(-33 \mathrm{u})$ is not observed in MALDI $\mathrm{MS}^{2}$ spectra, however quite abundant ions are created through the water loss $\left[\mathrm{M}+\mathrm{H}-\mathrm{H}_{2} \mathrm{O}\right]^{+}(-18 \mathrm{u})$, more intense for the longer normal alkyl chains R (for Et 27\%, n$\operatorname{Pr} 44 \%$ and $n$-Bu $29 \%$ of relative abundance), which suggests that carbonyl oxygen atom is involved and one of the protons is taken from neighboring alkyl (whereas the second one can originate from the acidic MALDI matrix). The other characteristic MALDI MS/MS dissociation of compounds studied feature is the elimination of methanol (from protonated colchicine) or analogously thiol RSH molecules from respective thio derivatives 1-5. This loss is depicted in Scheme 2 as $[\mathrm{M}+\mathrm{H}-\mathrm{RXH}]$, where $\mathrm{X}$ stands for $\mathrm{O}$

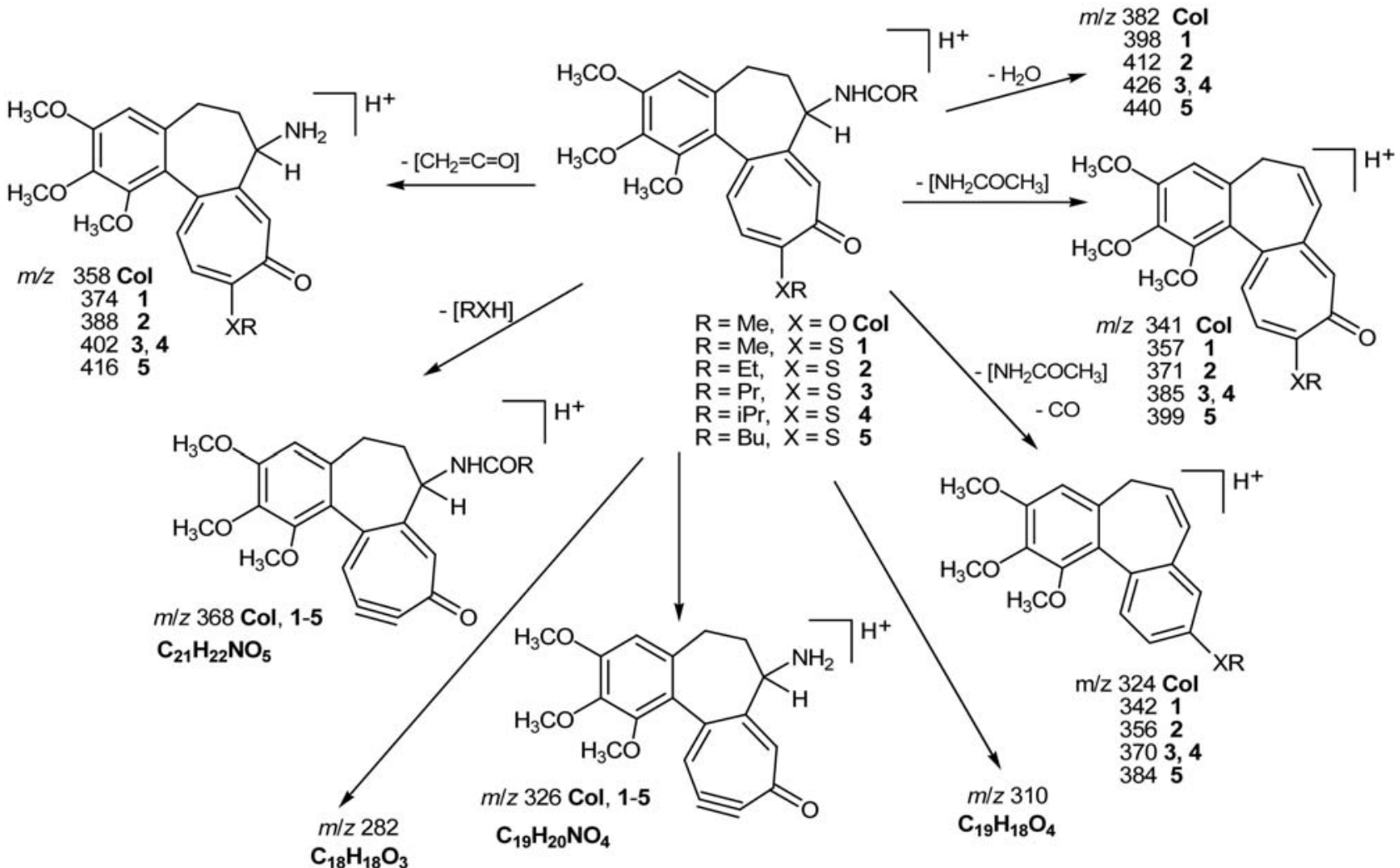

Scheme 2. Positive ion mode MALDI-QTOF MS/MS fragmentation pattern of $[\mathrm{M}+\mathrm{H}]^{+}$ions for $\mathbf{C o l}$ and $\mathbf{1}-\mathbf{5}$ at collision energy $\mathrm{CE}=20 \mathrm{eV}$ considered as the most probable according to the fragment ions observed. 


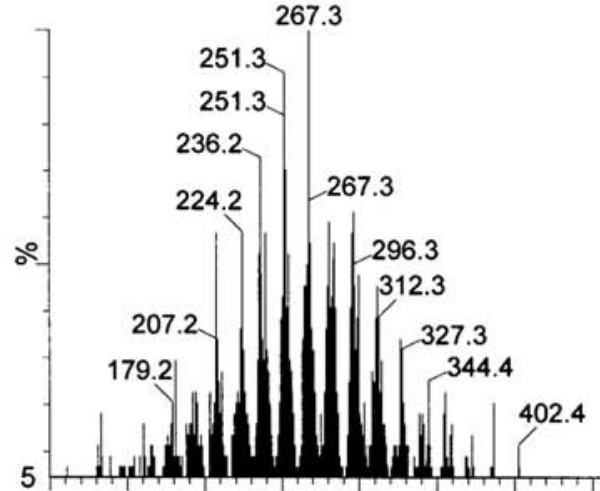

SAMPLE_16638 $18(0.182) \mathrm{Cm}(2: 50)$

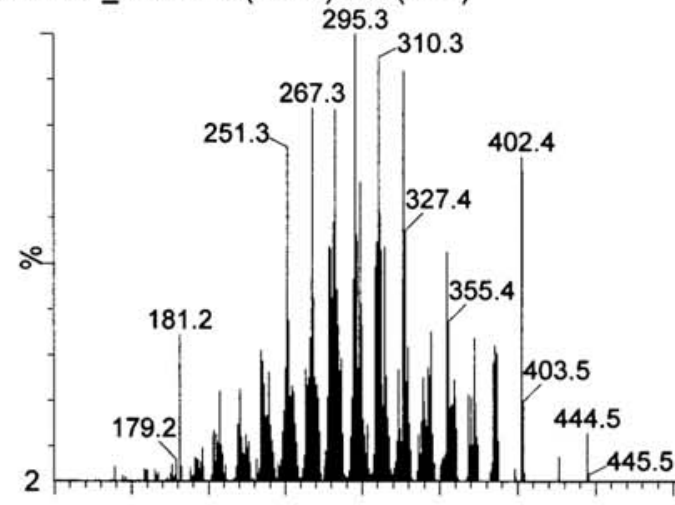

SAMPLE_16637 $38(0.383) \mathrm{Cm}(2: 50)$

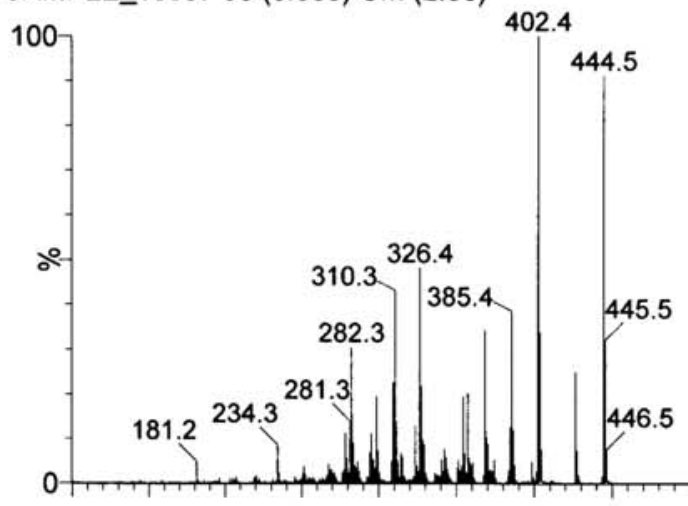

SAMPLE_16636 $18(0.182) \mathrm{Cm}(2: 50)$

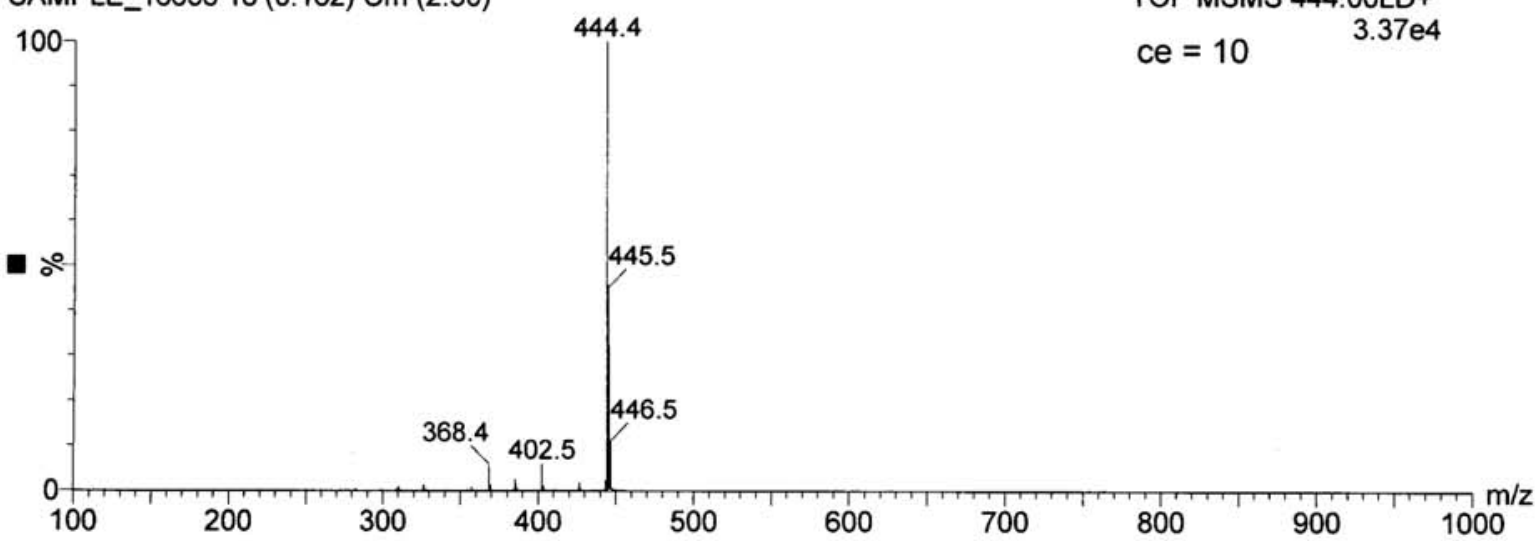

Fig. 3. MALDI TOF MS/MS spectra of precursor ion $[\mathrm{M}+\mathrm{H}]^{+}$i.e. protonated $10-n$-propylthiocolchicine $3(\mathrm{~m} / z$ 444) at $\mathrm{CE}=10,20,30 \mathrm{and} 40 \mathrm{eV}$. 
or S. The resulting fragment ion appears at $m / z 368$ regardless the substituent in position 10 of the colchicine skeleton. The signal of the highest abundance detected in the spectra of Col and 1-4 at CE $=20 \mathrm{eV}$ are formed through the ketene $\left(\mathrm{CH}_{2}=\mathrm{C}=\mathrm{O}\right)$ elimination from the $[\mathrm{M}+\mathrm{H}]^{+}$ions. These fragment ions appear at $m / z$ corresponding to [M-42] (Table 4 , Figure 3 ). The loss of ketene ( $42 \mathrm{u}$ ) is very common in acetyl moiety-containing molecules, for example acetates or acetamides. $^{26-30}$
Other decomposition reactions include the loss of acetamide molecule $\mathrm{H}_{2} \mathrm{NCOCH}_{3}$ (ions E, Table 4) and more complex losses of two or more species. Combined loss of ketene $\left(\mathrm{CH}_{2}=\mathrm{C}=\mathrm{O}\right)$ and methanol $\left(\mathrm{CH}_{3} \mathrm{OH}\right)$ molecules is intense only for the protonated colchicine molecule, leading to the fragment ion at $\mathrm{m} / \mathrm{z} 326$ (ion F, Table 4) whereas for compounds $\mathbf{1}-\mathbf{5}$ respective fragment ions at $m / z, 342(\mathbf{1}), 358(\mathbf{2}), 370(\mathbf{3}, \mathbf{4})$ and $384(\mathbf{5})$ are present in the spectra, but show low abundances. Much more

Table 4. Characteristic, the most abundant fragment ions derived from precursor ions $[\mathrm{M}+\mathrm{H}]^{+}$in MALDI TOF MS/MS for compounds Col and 1-5, matrix DIT; $\mathrm{m} / \mathrm{z}$ values and relative abundances (\%) at collision energies $\mathrm{CE}=20,30$ and $40 \mathrm{eV}$.

\begin{tabular}{|c|c|c|c|c|c|c|c|c|}
\hline \multirow[b]{2}{*}{ Ion } & \multirow[b]{2}{*}{ Elem. comp. } & \multicolumn{7}{|c|}{ Relative abundance $(\%)$ at $\mathrm{CE}=20 / 30 / 40 \mathrm{eV}$ (respectively) } \\
\hline & & $m / z$ & Col & 1 & 2 & 3 & 4 & 5 \\
\hline $\begin{array}{l}\mathbf{A} \\
{[\mathrm{M}+\mathrm{H}]^{+}}\end{array}$ & $\begin{array}{l}\mathrm{C}_{22} \mathrm{H}_{26} \mathrm{NO}_{6} \\
\mathrm{C}_{22} \mathrm{H}_{26} \mathrm{NO}_{5} \mathrm{~S} \\
\mathrm{C}_{23} \mathrm{H}_{28} \mathrm{NO}_{5} \mathrm{~S} \\
\mathrm{C}_{24} \mathrm{H}_{30} \mathrm{NO}_{5} \mathrm{~S} \\
\mathrm{C}_{25} \mathrm{H}_{32} \mathrm{NO}_{5} \mathrm{~S}\end{array}$ & $\begin{array}{l}400 \\
416 \\
430 \\
444 \\
458\end{array}$ & $100 / 30 / 0$ & $42 / 22 / 0$ & $70 / 35 / 0$ & $98 / 15 / 0$ & $90 / 6 / 0$ & $100 / 55 / 0$ \\
\hline $\begin{array}{l}\text { B } \\
{\left[\mathrm{M}+\mathrm{H}-\mathrm{H}_{2} \mathrm{O}\right]} \\
{[\mathrm{M}+\mathrm{H}-18]^{+}}\end{array}$ & $\begin{array}{l}\mathrm{C}_{22} \mathrm{H}_{24} \mathrm{NO}_{5} \\
\mathrm{C}_{22} \mathrm{H}_{24} \mathrm{NO}_{4} \mathrm{~S} \\
\mathrm{C}_{23} \mathrm{H}_{26} \mathrm{NO}_{4} \mathrm{~S} \\
\mathrm{C}_{24} \mathrm{H}_{28} \mathrm{NO}_{4} \mathrm{~S} \\
\mathrm{C}_{25} \mathrm{H}_{30} \mathrm{NO}_{4} \mathrm{~S}\end{array}$ & $\begin{array}{l}382 \\
398 \\
412 \\
426 \\
440\end{array}$ & $20 / 4 / 0$ & $17 / 0 / 0$ & $27 / 15 / 0$ & $44 / 8 / 0$ & $18 / 1 / 0$ & 29/15/0 \\
\hline $\begin{array}{l}\mathbf{C} \\
{[\mathrm{M}+\mathrm{H}-\mathrm{RXH}]^{+}} \\
\mathrm{X}=\mathrm{O}, \mathrm{S}\end{array}$ & $\mathrm{C}_{21} \mathrm{H}_{22} \mathrm{NO}_{5}$ & 368 & $8 / 3 / 0$ & $19 / 0 / 0$ & $30 / 40 / 0$ & $54 / 28 / 5$ & $30 / 10 / 0$ & $50 / 20 / 7$ \\
\hline $\begin{array}{l}\text { D } \\
{\left[\mathrm{M}+\mathrm{H}-\mathrm{CH}_{2}=\mathrm{C}=\mathrm{O}\right]^{+}} \\
{[\mathrm{M}+\mathrm{H}-42]^{+}}\end{array}$ & $\begin{array}{l}\mathrm{C}_{20} \mathrm{H}_{24} \mathrm{NO}_{5} \\
\mathrm{C}_{20} \mathrm{H}_{24} \mathrm{NO}_{4} \mathrm{~S} \\
\mathrm{C}_{21} \mathrm{H}_{26} \mathrm{NO}_{4} \mathrm{~S} \\
\mathrm{C}_{22} \mathrm{H}_{28} \mathrm{NO}_{4} \mathrm{~S} \\
\mathrm{C}_{23} \mathrm{H}_{30} \mathrm{NO}_{4} \mathrm{~S}\end{array}$ & $\begin{array}{l}358 \\
374 \\
388 \\
402 \\
416\end{array}$ & $60 / 21 / 0$ & $100 / 33 / 7$ & $100 / 100 / 0$ & $100 / 75 / 3$ & $100 / 40 / 0$ & 90/98/0 \\
\hline $\begin{array}{l}\mathbf{E} \\
{\left[\mathrm{M}+\mathrm{H}-\mathrm{NH}_{2} \mathrm{COCH}_{3}\right]^{+}} \\
{[\mathrm{M}+\mathrm{H}-59]^{+}}\end{array}$ & $\begin{array}{l}\mathrm{C}_{20} \mathrm{H}_{21} \mathrm{O}_{5} \\
\mathrm{C}_{20} \mathrm{H}_{21} \mathrm{O}_{4} \mathrm{~S} \\
\mathrm{C}_{21} \mathrm{H}_{23} \mathrm{O}_{4} \mathrm{~S} \\
\mathrm{C}_{22} \mathrm{H}_{25} \mathrm{O}_{4} \mathrm{~S} \\
\mathrm{C}_{23} \mathrm{H}_{27} \mathrm{O}_{4} \mathrm{~S} \\
\end{array}$ & $\begin{array}{l}341 \\
357 \\
371 \\
385 \\
399 \\
\end{array}$ & $37 / 10 / 0$ & $31 / 10 / 0$ & $45 / 43 / 3$ & $60 / 40 / 4$ & $30 / 15 / 0$ & $42 / 48 / 1$ \\
\hline $\begin{array}{l}\mathbf{F} \\
{\left[\mathrm{M}+\mathrm{H}-\mathrm{CH}_{2}=\mathrm{C}=\mathrm{O}, \mathrm{CH}_{3} \mathrm{OH}\right]^{+}}\end{array}$ & $\begin{array}{l}\mathrm{C}_{19} \mathrm{H}_{20} \mathrm{NO}_{4} \\
\mathrm{C}_{19} \mathrm{H}_{20} \mathrm{NO}_{3} \mathrm{~S} \\
\mathrm{C}_{20} \mathrm{H}_{22} \mathrm{NO}_{3} \mathrm{~S} \\
\mathrm{C}_{21} \mathrm{H}_{24} \mathrm{NO}_{3} \mathrm{~S} \\
\mathrm{C}_{22} \mathrm{H}_{26} \mathrm{NO}_{3} \mathrm{~S}\end{array}$ & $\begin{array}{l}326 \\
342 \\
358 \\
370 \\
384\end{array}$ & $40 / 52 / 12$ & & $9 / 16 / 2$ & $12 / 0 / 0$ & $10 / 18 / 0$ & $\begin{array}{l}2 / 6 / 0 \\
10 / 12 / 5\end{array}$ \\
\hline $\begin{array}{l}\mathbf{G} \\
{\left[\mathrm{M}+\mathrm{H}-\mathrm{CH}_{2}=\mathrm{C}=\mathrm{O}, \mathrm{RXH}\right]^{+}}\end{array}$ & $\mathrm{C}_{19} \mathrm{H}_{20} \mathrm{NO}_{4}$ & 326 & $40 / 52 / 12$ & $35 / 80 / 25$ & $34 / 45 / 11$ & $67 / 93 / 15$ & $38 / 64 / 24$ & $42 / 80 / 23$ \\
\hline $\begin{array}{l}\mathbf{H} \\
{\left[\mathrm{M}+\mathrm{H}-{ }^{-} \mathrm{NHCOCH}_{3}, \mathrm{RXH}\right]^{+}}\end{array}$ & $\mathrm{C}_{19} \mathrm{H}_{18} \mathrm{O}_{4}$ & 310 & $40 / 90 / 25$ & $30 / 65 / 20$ & $50 / 55 / 25$ & $62 / 95 / 45$ & $40 / 85 / 34$ & $42 / 100 / 35$ \\
\hline $\begin{array}{l}\mathbf{J} \\
{\left[\mathrm{M}+\mathrm{H}-\mathrm{CH}_{2}=\mathrm{C}=\mathrm{O}, \mathrm{RXH}, \mathrm{CO}\right]^{+}}\end{array}$ & $\mathrm{C}_{18} \mathrm{H}_{20} \mathrm{NO}_{3}$ & 298 & $17 / 40 / 15$ & $23 / 85 / 30$ & $20 / 45 / 15$ & $16 / 80 / 61$ & $17 / 56 / 40$ & $18 / 62 / 40$ \\
\hline $\begin{array}{l}\mathbf{K} \\
{\left[\mathrm{M}+\mathrm{H}-\mathrm{NHCOCH}_{3}, \mathrm{RXH}, \mathrm{CO}\right]^{+}}\end{array}$ & $\mathrm{C}_{18} \mathrm{H}_{18} \mathrm{O}_{3}$ & 282 & $25 / 82 / 44$ & $20 / 55 / 26$ & $35 / 30 / 8$ & $40 / 83 / 56$ & $25 / 95 / 64$ & $20 / 85 / 45$ \\
\hline $\mathbf{L}$ & $\mathrm{C}_{17} \mathrm{H}_{15} \mathrm{O}_{3}$ & 267 & $5 / 78 / 100$ & $4 / 55 / 95$ & $8 / 50 / 85$ & $8 / 85 / 100$ & $3 / 60 / 91$ & $4 / 60 / 85$ \\
\hline$\overline{\mathbf{M}}$ & $\mathrm{C}_{17} \mathrm{H}_{15} \mathrm{O}_{2}$ & 251 & $2 / 40 / 70$ & $3 / 65 / 100$ & $5 / 40 / 100$ & $6 / 77 / 90$ & $0 / 50 / 100$ & $3 / 55 / 100$ \\
\hline $\mathbf{N}$ & $\mathrm{C}_{17} \mathrm{H}_{14} \mathrm{O}$ & 234 & $5 / 18 / 10$ & $5 / 15 / 8$ & $5 / 15 / 7$ & $10 / 36 / 28$ & $6 / 15 / 18$ & $7 / 28 / 25$ \\
\hline$\overline{\mathbf{O}}$ & $\mathrm{C}_{13} \mathrm{H}_{9} \mathrm{O}$ & 181 & $3 / 15 / 25$ & $5 / 18 / 45$ & $4 / 4 / 35$ & $8 / 35 / 15$ & $4 / 20 / 27$ & $3 / 23 / 22$ \\
\hline
\end{tabular}


abundant are fragment ions $\mathrm{G}$ formed through the combined loss of ketene and RXH molecules (where X stands for $\mathrm{O}$ for colchicine and $\mathrm{S}$ for 10-alkylthiocolchicines). In the case of colchicine $\mathrm{RXH}=\mathrm{CH}_{3} \mathrm{OH}$, meaning that $\mathrm{CH}_{3} \mathrm{O}$ moiety originates mainly from the substituent in position 10 of colchicine ring and not from the methoxy group attached to the six-membered aromatic ring. Dissociations leading to the ions $\mathrm{H}(\mathrm{m} / \mathrm{z}, 310)$ and $\mathrm{K}(\mathrm{m} / \mathrm{z}$ 282) seem to involve radical cleavage, consisting in elimination of ${ }^{\circ} \mathrm{NHCOCH}_{3}$, combined with $\mathrm{RXH}$ and $\mathrm{CO}$ losses.

It should be pointed out that the main, most intense fragment ions from MALDI CID experiment for colchicine and their elemental formula proposed are in perfect agreement with the colchicine fragment ions reported recently by Vaclavik et al., who used positive ESI full MSdd-MS/MS mode. ${ }^{31}$ The authors gave following distinctive fragment ions which originate from $[\mathrm{M}+\mathrm{H}]^{+}$ion of colchicine: $\mathrm{m} / \mathrm{z}$ 382, 358, 341, 310, 282. Their $\mathrm{m} / \mathrm{z}$ values, measured with high resolution, fully confirm their elemental composition, which are consistent with the ones given in Table 4 (ion $\mathrm{B}, \mathrm{m} / z$ 382, $\mathrm{C}_{22} \mathrm{H}_{24} \mathrm{NO}_{5}$; ion $\mathrm{D}, \mathrm{m} / \mathrm{z}$ $358, \mathrm{C}_{20} \mathrm{H}_{24} \mathrm{NO}_{5}$; ion $\mathrm{E}, \mathrm{m} / \mathrm{z} 341, \mathrm{C}_{20} \mathrm{H}_{21} \mathrm{O}_{5}$; ion $\mathrm{H}, \mathrm{m} / \mathrm{z}$ $310, \mathrm{C}_{19} \mathrm{H}_{18} \mathrm{O}_{4}$; ion $\mathrm{K}, \mathrm{m} / \mathrm{z}, 282, \mathrm{C}_{18} \mathrm{H}_{18} \mathrm{O}_{3}$ ).

The schematic representation of the proposed fragmentation of $[\mathrm{M}+\mathrm{H}]^{+}$ions of Col and 1-5 at $\mathrm{CE}=20$ is shown in Scheme 2 and main fragment ions present at different $C E$ values $(\mathrm{m} / \mathrm{z}$ values and relative abundances) are listed in Table 4.

We have also tested the effect of collision energy (CE) applied on the precursor ion abundance (absolute values, measured in counts). CE is the most important factor of CID conditions, because it determines the kinetic energy of the sample ion which is transformed into internal energy by collisions. The increase of CE and, in consequence, of internal energy of the ion results in the ion decomposition into fragments. The abundances of precursor ions of interest at different values of cone voltage are listed in Table 5. The profile for isopropyl derivative $\mathbf{4}$ is distinct from the others because the precursor ion $[\mathrm{M}+\mathrm{H}]^{+}$is very abundant at collision energy $10 \mathrm{eV}$ and its abundance drops rapidly with increasing collision energy (not shown graphically, because the plot is out of scale). The abun-

Table 5. Abundances (measured in counts) of precursor ions $[\mathrm{M}+\mathrm{H}]^{+}$at different values of collision energy $\mathrm{CE}(\mathrm{eV})$ for $\mathbf{C o l}$ and 1-5

\begin{tabular}{lllll}
\hline \multicolumn{5}{c}{ Abundance, counts $\times \mathbf{1 0}^{\mathbf{3}}$} \\
CE & $\mathbf{1 0}$ & $\mathbf{2 0}$ & $\mathbf{3 0}$ & $\mathbf{4 0}$ \\
Comp. & & & 0.315 & 0.001 \\
Col & 0.771 & 1 & 0.047 & 0.001 \\
$\mathbf{1}$ & 1 & 0.871 & 0.209 & 0 \\
$\mathbf{2}$ & 1 & 0.972 & 0.062 & 0 \\
$\mathbf{3}$ & 0.667 & 1 & 0.012 & 0 \\
$\mathbf{4}$ & 2.080 & 0.571 & 0.365 & 0 \\
$\mathbf{5}$ & 0.341 & 1 & & \\
\hline
\end{tabular}

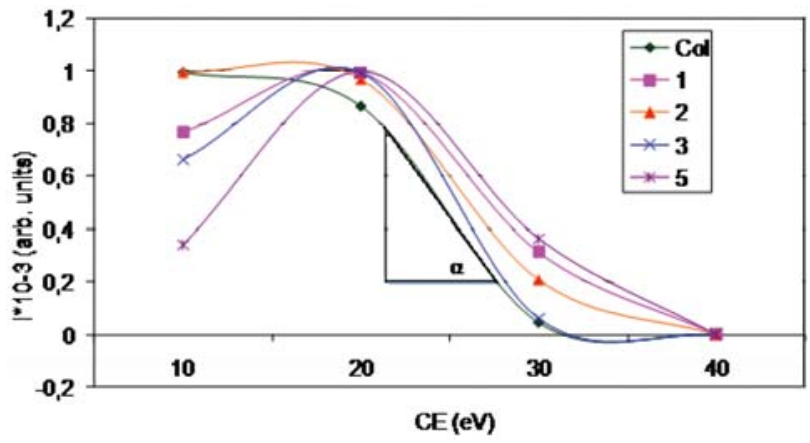

Fig. 4. Precursor ion $[\mathrm{M}+\mathrm{H}]^{+}(\mathrm{Col}, \mathbf{1}, \mathbf{2}, \mathbf{3}, \mathbf{5})$ abundance breakdown plot against collision energy.

dances of precursor ion $[\mathrm{M}+\mathrm{H}]^{+}$against collision energy dependence for the precursor ions, derived from compounds Col 1, 2, 3, and 5, present characteristic breakdown plot, shown in Figure 4.

The rate according to which the ion intensity falls along with increasing collosion energy can be considered a measure of the stability of this ion, and so if the curve $I=f(\mathrm{CE})$ falls steeply after the maximum point, the ion decays quickly with the increase of collision energy, whereas if the curve falls gently after going through a maximum, it means that the ion is more stable. This can be quantified by calculating the tangent of the angle of the slope of the linear portion of the curve to the axis $x(\operatorname{tg} \alpha$, angle $\alpha$ noted on the chart). The higher the value of $\operatorname{tg} \alpha$, the more steep is the decrease in intensity of the $[\mathrm{M}+\mathrm{H}]^{+}$ ion, and so less stable is this particular ion.

The calculated values of $\operatorname{tg} \alpha$ for a linear portion of the graph showing relationship between the precursor ion intensity $I$ and collision energy $\mathrm{CE}$ for $[\mathrm{M}+\mathrm{H}]^{+}$ion of each tested compound (Col and 1-5) are:

$\operatorname{tg} \alpha(\mathbf{C o l})=1.53, \operatorname{tg} \alpha(\mathbf{1})=1.22, \operatorname{tg} \alpha(\mathbf{2})=1.40, \operatorname{tg}$ $\alpha(\mathbf{3})=1.72, \operatorname{tg} \alpha(\mathbf{4})=1.82, \operatorname{tg} \alpha(\mathbf{5})=1.25$

From the above data can be shown that there is no linear relationship between the number of carbon atoms in the normal alkyl chain of the substituent $\mathrm{R}$ in position 10 of alkylthiocolchicines and stability of the $[\mathrm{M}+\mathrm{H}]^{+}$ion. Initially, with increasing chain length the ions of interest are less stable at higher collision energy CE, but for $n$ butyl its stability is increasing. Protonated $\mathbf{4}$, the only ion containing branched chain (isopropyl), appears to be more sensitive to the increase in collision energy than the others and this feature may be helpful in distinguishing isomers.

\section{Conclusions}

In this report we examined a series of colchicine derivatives, i.e. 10-alkylthiocolchicines 1-5, which have been obtained as model compounds of changed geometry 
in comparison with colchicine itself. The introduced alkyl chain is likely to change the key-lock binding of the compounds obtained in the living cells.

Electron-ionization mass spectra can serve as fingerprints of particular compounds, since they are unique for every compound studied. Analysis of EI mass spectra showed that the relative abundance of the molecular ion a and the fragment ions presented in Table 3, as well as of coefficients $\mu_{1}-\mu_{5}$ were the most useful in the differentiation of isomeric derivatives of the colchicines studied herein. The fragmentation rules discussed here could facilitate the rapid screening and structural characterization of colchicines extracts.

MALDI TOF and Q-TOF spectra not only confirm the identity of compound (exact mass), but also serve as a proof of complete derivatization. The common losses observed in MALDI MS/MS technique, i.e. loss of ketene $\mathrm{CH}_{2}=\mathrm{C}=\mathrm{O}$, thiol R-XH (or methanol for colchicine, respectively), acetamide $\mathrm{NH}_{2} \mathrm{COCH}_{3}$, and combined above losses, involving also carbon oxide loss can be used as additional fingerprints for the investigated species. Collision-induced dissociation experiments enable the estimation of ion stability. The proper matrix choice for the specific class of compounds prior to testing their interactions with macromolecules (for example proteins) is crucial. Among the matrices used-DHB, SA, CHCA and DIT-the last one appeared to give the best response and signal-tonoise ratio. The MS/MS experiment with dithranol as a matrix evoked the collision-induced fragmentation of protonated ions $[\mathrm{M}+\mathrm{H}]^{+}$. The $[\mathrm{M}+\mathrm{H}]^{+}$ion abundance decrease with the increasing $\mathrm{CE}$ is the fastest for isopropyl containing compound and this feature can be the basis for differentiation between branched and unbranched alkyl substituted thiocolchicines.

\section{Aknowledgement}

Support from the National Centre for Research and Development (Poland) under research grant PBS1/A9/13/ 2012 , is gratefully acknowledged by G. Bartkowiak.

\section{References}

1. H. G. Capraro, A. Brossi in: A. Brossi (Ed): The alkaloids, Academic Press, New York, 1984, vol. 23, pp. 1-70.

2. F .Chemnitius, Zur Darstellung des Colchicins, J. Prakt. Chem., 1928, 118, 29-32.

http://dx.doi.org/10.1002/prac.19281180106

3. R. L. Margolis, L. Wilson, Nature 1981, 293, 705-711. http://dx.doi.org/10.1038/293705a0

4. P. Dustin, Microtubules, Springer - Verlag, New York, USA, 1984, pp. 171-233.

http://dx.doi.org/10.1007/978-3-642-69652-7_8

5. M. Klintschar, C. Beham-Schmidt, H. Radner, G. Henning,
P. Rol, Forensic Sci. Inter. 1999, 106, 191-200. http://dx.doi.org/10.1016/S0379-0738(99)00191-7

6. D. C. Rockey, Clin. Gastroenterol. H. 2005, 3, 95-100. http://dx.doi.org/10.1016/S1542-3565(04)00445-8

7. L. Wilson, I. Meza, J. Cell Biol. 1973, 58, 709-719. http://dx.doi.org/10.1083/jcb.58.3.709

8. (a) J. Kurek, Wł. Boczoń, K. Myszkowski, M. Murias, T. Borowiak, I. Wolska, Lett. Drug Des. Discov. 2014, 11, 279289, (b) patent application J. Kurek, PL P.393722 2011. http://dx.doi.org/10.2174/15701808113106660086

9. S. G. Kulkarni, A. Warbritton, T. J. Bucci, H. M. Mehendale, Toxicology 1997, 120, 79-88.

http://dx.doi.org/10.1016/S0300-483X(97)03627-5

10. M. A. Iorio, A. Mazzeofarina, G. Cavina, L. Boniforti, A. Brossi, Heterocycles 1980, 14, 625-630.

http://dx.doi.org/10.3987/R-1980-05-0625

11. P. Qiu, X. Chen, X. Chen, L. Lin, C. Ai, J. Chromatography B 2008, 875, 471-477. http://dx.doi.org/10.1016/j.jchromb.2008.09.034

12. W. C. Wildman, B. A. Pursey, in: R.H. Mansche (Ed): The Alkaloids, Academic Press, New York, 1962, vol. 11, 407458.

13. J. M. Wilson, M. Ohashi, H. Budzikiewicz, F. Šantavý, C. Djerassi, Tetrahedron 1963, 19, 2225-2231. http://dx.doi.org/10.1016/0040-4020(63)85037-1

14. Ch.-M. Li, Y. Lu, Ahn Sunjoo, R. Narayanan, D. D. Miller, T. J. Dalton, J Mass. Spectrom. 2010, 45, 1160-1170. http://dx.doi.org/10.1002/jms.1804

15. F. Q. Alali, A. Gharaibeh, A. Ghawanmeh, K. Tawaha, N. H. Oberlies, Phytochem. Anal. 2008, 19, 385-394. http://dx.doi.org/10.1002/pca.1060

16. G. Hamscher, B. Priess, H. Nau, E. Panariti, Anal. Chem. 2005, 77, 2421-2425. http://dx.doi.org/10.1021/ac048668+

17. J. Beyer, F. T. Peters, T. Kraemer, H. H. Maurer, J. Mass. Spectrom. 2007, 42, 621-633. http://dx.doi.org/10.1002/jms.1191

18. Y. Jiang, J. Wang, Y. Wang, H. Li, J. P. Fawcett, J. Gu, J. Chromatography B 2007, 850, 1-2, 564-568. http://dx.doi.org/10.1016/j.jchromb.2006.12.022

19. A. Vinnersten, S. Larsson, Biochem. System. Ecol. 2010, 38, 1193-1198. http://dx.doi.org/10.1016/j.bse.2010.12.004

20. W. Li, Y. Sun, J. F. Fitzloff, R. B. van Breemen, Chem. Res. Toxicol. 2002, 15, 1174-1178. http://dx.doi.org/10.1021/tx025559m

21. Z. Nowakowska, Rapid Commun. Mass Spectrom. 2005, 19, 1355-1358. http://dx.doi.org/10.1002/rcm.1919

22. E. Wyrzykiewicz, Z. Nowakowska, J. Mass Spectrom. 1995, 30, 269-274. http://dx.doi.org/10.1002/jms.1190300207

23. G. Bartkowiak, Rapid Commun. Mass Spectrom. 2005, 19 , 1207-1212. http://dx.doi.org/10.1002/rcm.1898

24. P. Hannewald, B. Maunit, J.-F.Muller, Anal. Chem. 2006, 78, 4390-4397. http://dx.doi.org/10.1021/ac0601462

25. Z.-W. Chen, L.-H. Chen, N. Akentieva, C. F. Lichti, R. Darbandi, R. Hastings, D. F. Covey, D. E. Reichert, R. R. Townsend, A. S. Evers, Electrophoresis 2012, 33, 666-674. http://dx.doi.org/10.1002/elps.201100434 
26. R. M. Smith, in J. Wiley, $2^{\text {nd }}$ Ed.: Understanding mass spectra. A basic approach, ISBN: 978-0-471-47934-5, 2004

27. I. Komaromi, A. Somogyi, V. H. Wysocki, Int. J. Mass Spectrom. 2005, 241, 315-323. http://dx.doi.org/10.1016/j.ijms.2004.12.033

28. J. A. Benbow, J. C. Wilson, J. H. Bowie, J. Mass Spectrom. Ion Phys. 1978, 26, 173-180.

http://dx.doi.org/10.1016/0020-7381(78)80020-5
29. L. B. Jensen, S. Hammerum, Europ. J. Mass Spectrom., 2004, 10, 783-790. http://dx.doi.org/10.1255/ejms.706

30. B. A. Budnik, K. F. Haselmann, N. Yu, V. I. Elkin, R. Gorbach, A. Zubarev, Anal. Chem. 2003, 75, 5994-6001. http://dx.doi.org/10.1021/ac034477f

31. L. Vaclavik, A. J. Krynitsky, J. I. Rader, Anal. Chim. Acta 2014, 810, 45-60.

http://dx.doi.org/10.1016/j.aca.2013.12.006

\section{Povzetek}

Raziskali smo obnašanje petih 10-alkiltiokolhicinskih derivatov v masnem spektrometru pod pogoji elektronske ionizacije in z MALDI-TOF MS tehniko. Preučili smo fragmentacijske vzorce kolhicinskih derivatov po elektronski ionizaciji kot tudi masne spektre, dobljene po kolizijsko-inducirani disociaciji (CID) MALDI ter tako dobili pomembne strukturne informacije. Prepričani smo, da gre v prispevku za prvi literaturni opis MALDI MS/MS podatkov za kolhicin in njegove alkiltio derivate. Znano je namreč, da lahko podatke, dobljene iz masnih spektrov, koristno uporabimo za identifikacijo in kvantitativno določitev naravnih in modificiranih alkaloidov iz kolhicinske skupine. Podrobni fragmentacijski vzorci, ki jih opisujemo, so lahko koristni tudi pri karakterizaciji kolhicinskih derivatov drugačnih tipov. Zanimala nas je tudi uporabnost različnih ionizacijskih tehnik za analizo spojin tega tipa. Glede na znano citotoksično aktivnost proti različnim tumorskim linijam predvidevamo, da bi lahko tudi 10-alkiltiokolhicini nastopali kot aktivne sestavine zdravil proti raku. če bodo tovrstne spojine kdaj postale uporabne v medicini, bo namreč nujno spremljati njihovo razporeditev v organizmu in tudi njihov metabolizem, pri čemer se ne bo mogoče izogniti spektroskopskim oz. spektrometričnim metodam. Značilni fragmentacijski ioni, ki smo jih opazili, bi bili lahko torej uporabni pri selektivnem spremljanju reakcij (SRM) kot metodi, za določanje analogov kolhicina. 